\title{
Molecularly directed therapy of advanced/metastatic non-small cell lung cancer
}

\author{
Shiruyeh Schokrpur, MD, $\mathrm{PhD}^{1}$ (D), Sandip Patel, $\mathrm{MD}^{1}$ (D) \\ ${ }^{1}$ Hematology and Oncology, University of California, San Diego \\ Keywords: tyrosine kinase inhibitors (TKIs), non-small cell lung cancer (NSCLC), osimertinib, alectinib, sotorasib, larotrectinib, selpercatinib, \\ pralsetinib, capmatinib, tepotinib
}

https://doi.org/10.53876/001c.31316

International Journal of Cancer Care and Delivery

Vol. 2, Issue 1, 2022

Lung cancer is the leading cause of cancer deaths in the United States and worldwide. Recent advances in molecularly directed therapy have expanded treatment options and improved outcomes for patients with advanced or metastatic disease. Subsequent generation inhibitors have been developed targeting EGFR and ALK alterations to guide current management. Novel treatment strategies have been developed for patients with additional alterations, including EGFR exon 20 insertion, ROS1 fusions, BRAF V600E mutations, KRAS G12C mutations, NTRK fusions, RET rearrangements, and MET exon 14 skipping. The increased rate of development and approval of these targeted agents provides hope for further discovery and refinement in our treatments for patients with metastatic NSCLC. New treatment options and combinations promise to push this field forward in coming years.

\section{ARTICLE HIGHLIGHTS}

- Targeted therapies are available for nine classes of mutations in NSCLC

- Herein we discuss the clinical trials laying the foundation for their use in first-line and subsequent settings

- Current and future studies will lead to the discovery of next-line therapies to address resistance mutations and novel targetable genes

\section{INTRODUCTION}

Lung cancer accounts for around 150,000 deaths annually and is the leading cause of cancer-related mortality while being the second most common cause of cancer in the United States. ${ }^{1}$ Given its status as the leading cause of cancer death, there is an urgent need to identify new treatment options and improve our current therapies for this condition. The management of non-small cell lung cancer (NSCLC) has experienced a revolution thanks to the development of molecularly targeted therapies that have improved response rates and duration of response in many patients. It is estimated that approximately half of the patients with NSCLC harbor activating mutations, including alterations in EGFR in $15.6-22 \%, K R A S$ in $25 \%, A L K$ in $1.9-8.5 \%, E R B B 2$ in $2.4 \%$, and more, depending on the population studied. ${ }^{2-4}$ These changes provide attractive targets for our growing armamentarium of oncogene targeted therapy. Recent and ongoing studies have shown an amazing ability to improve our outcomes for patients with newer TKIs targeting EGFR mutations and $A L K$ rearrangements, as well as open new avenues of therapy for patients with other alterations, such as KRAS G12C mutations, MET exon 14 skipping, and RET rearrangements, and more. In this review, we outline the key clinical trials that guide our current molecularly targeted management of NSCLC.

\section{EGFR EXON 19 DELETIONS AND L858R MUTATIONS}

There are several options for the treatment of NSCLC with EGFR exon 19 deletions or L858R mutations. The preferred agent in this class is osimertinib, which received this status based on results from the FLAURA study. ${ }^{5,6}$ This trial compared osimertinib $80 \mathrm{mg}$ daily with standard EGFR-tyrosine kinase inhibitor (TKI) therapy, involving gefitinib at $250 \mathrm{mg}$ daily or erlotinib at $150 \mathrm{mg}$ daily, in the first-line setting. With 556 patients, median overall survival (OS) with osimertinib was 38.6 months (95\% Confidence interval (CI), 34.5-41.8) compared to 31.8 months (95\% CI 26.6-36.0). This comparison was found to be statistically significant, with a hazard ratio (HR) of 0.046 (95\% CI, 0.64-1.00). The rates of grade 3 or higher adverse events were $32 \%$ in the osimertinib group and $41 \%$ in the EGFR-TKI group, as reported by Soria et al. In an update in 2020, Ramalingam et al. reported $42 \%$ and $47 \%$, respectively, for grade 3 or higher adverse events. Of note, patients receiving osimertinib had a longer duration of exposure, at 20.7 versus 11.5 months, respectively.

Other potential options for first-line therapy of patients with NSCLC with EGFR exon 19 deletions or L858R mutations include erlotinib, ${ }^{7-9}$ afatinib, ${ }^{10-14}$ gefitinib, ${ }^{15}$ dacomitinib, ${ }^{16,17}$ erlotinib plus ramicirumab, ${ }^{18}$ and erlotinib 
plus bevacizumab. ${ }^{19}$ Results from trials demonstrating the efficacy of these agents can be found in Table 1. Notably, combination therapy appears to have a median progression-free survival (PFS) more comparable to what is found in the FLAURA study, with erlotinib $150 \mathrm{mg}$ daily plus ramucirumab showing a 19.4 month (95\% CI, 15.4-21.6) median PFS compared to 12.4 months (95\% CI, 0.46-0.76) for erlotinib. ${ }^{18}$ This was statistically significant, with a HR of 0.59 (95\% CI, 0.46-0.76) and $\mathrm{p}<0.0001$. Serious adverse effects were more likely in the combination group, with $29 \%$ versus $21 \%$ experiencing these, respectively. Median overall survival data for this study has not yet been reported.

\section{EGFR EXON 20 INSERTION}

A couple recent studies have led to the accelerated approvals of amivantamab and mobocertinib for the treatment of NSCLC with EGFR exon 20 insertion. The phase I CHRYSALIS study treated patients who progressed following platinum chemotherapy with amivantamab $1400 \mathrm{mg}$ weekly for the first four weeks, followed by the same dose every two weeks. ${ }^{20}$ This study showed an ORR of $40 \%$ (95\% CI, 29-51) and a median PFS of 8.3 months (95\% CI, 6.5-10.9). Median OS was 22.8 months (95\% CI, 14.6-NR). Grade 3 or higher adverse events were experienced by $35 \%$ of the safety population and $39 \%$ of those treated with the recommended phase 2 dose. Infusion-related reactions were common but generally isolated to the first two doses of treatment and can be managed with premedication and lowering of infusion rate.

Zhou et al. recently reported the results of a pooled phase I/II study evaluating the efficacy of mobocertinib 160 mg daily in patients with platinum-pretreated NSCLC and EGFR exon 20 insertion. ${ }^{21}$ These patients showed an ORR of $28 \%$ (95\% CI, 20-37), and a median PFS of 7.3 months (95\% CI, 5.5-9.2). The median OS for this group was 24.0 months (95\% CI, 14.6-28.8). Grade 3 or higher adverse events were experienced in $69 \%$ of patients.

\section{$A L K$ FUSION}

Several second- and further-generation TKIs have demonstrated efficacy in NSCLC with $A L K$ fusions, leading to no defined preferred agent. The ALEX study evaluating alectinib $600 \mathrm{mg}$ BID in the first-line setting in patients with $A L K$ fusions has demonstrated an impressive overall survival on this therapy, with the median not reached, compared to 57.4 months (95\% CI, 34.6-NR) with crizotinib 250 mg BID. ${ }^{22,23}$ The HR for this comparison was 0.67 (95\% CI, 0.46-0.98). The ORR was $82.9 \%$ (95\% CI, 76.0-88.5) in patients receiving alectinib compared to $75.5 \%$ (95\% CI, 67.8-82.1), though this difference was not found to be statistically significant. The median PFS did show a statistically significantly improved median PFS at 34.8 months (95\% CI, 17.7-NE) compared to 10.9 months (95\% CI, 9.1-12.9). The HR for this comparison was 0.43 (95\% CI, $0.32-0.58$ ), with $\mathrm{p}<0.0001$. The frequency of grade 3 or higher adverse events were reported by Peters et al. as $41 \%$ with alectinib and 50\% with crizotinib in 2017. In a 2020 up- date, Mok et al. reported similar rates between the groups, at $52.0 \%$ for alectinib and $56.3 \%$ for crizotinib.

The ALTA-1L study compared brigatinib $180 \mathrm{mg}$ daily to crizotinib $250 \mathrm{mg}$ BID in first-line treatment with patients with $A L K$ fusions. ${ }^{24,25}$ This study demonstrated an ORR of $74 \%$ (95\% CI, 66-81) for brigatinib compared to 62\% (95\% CI, 53-70) for crizotinib. This was statistically significant, with a HR of 1.73 (95\% CI, 1.04-2.88). Brigatinib had a median PFS of 24.0 months (95\% CI, 18.5-NR) compared to 11 months (95\% CI, 9.2-12.9) with crizotinib. Median OS has been reported as a HR of 0.92 (95\% CI, 0.57-1.47), with a lack of statistical significance, given $\mathrm{p}=0.771$. Patients experienced grade 3 or higher adverse events at a rate of $73 \%$ in the brigatinib group and $61 \%$ in the crizotinib group.

Provocative findings have been reported from the CROWN study, in particular for patients with CNS metastasis. ${ }^{26}$ Lorlatinib $100 \mathrm{mg}$ daily was compared to crizotinib $250 \mathrm{mg}$ BID. The ORR with lorlatinib was 76\% (95\% CI, 68-83) compared to $58 \%$ (95\% CI, 49-66) for crizotinib. This comparison has an OR of 2.25 (95\% CI, 1.35-3.89). The median PFS for lorlatinib was not reached and 9.3 months (95\% CI, 7.6-11.1) for crizotinib. This difference was statistically significant, with a HR of 0.28 and $p<0.001$. Median OS has not yet been reported, but the investigators did report a HR of 0.72 (95\% CI, 0.41-1.25) for this metric. Grade 3 or higher adverse effects occurred in $72 \%$ of lorlatinib patients and $56 \%$ of crizotinib patients. Table 2 serves to summarize these and subsequent studies discussed leading to the approval of targeted agents for molecularly altered NSCLC.

\section{ROS1 FUSION}

Results from several phase I and II studies have guided the management of NSCLC with ROS1 fusion. Dziadziuszko et al. summarized three such studies which explored the response of patients who were ROS1-inhibitor naive to entrectinib $\geqslant 600 \mathrm{mg}$ daily. ${ }^{27}$ Patients who received this treatment had an ORR of 67.1\% (95\% CI, 59.3-74.3). Median PFS was 15.7 months (95\% CI, 11.0-21.1). median OS was immature at the time of publication.

The PROFILE 1001 study evaluated the use of crizotinib $250 \mathrm{mg}$ BID in ROS1-inhibitor naive patients. ${ }^{28,29}$ The ORR in this population was $72 \%$ (95\% CI, 58-83). The patients had a 19.3 month (95\% CI, 15.2-39.1) median PFS and median OS of 51.4 months (29.3-NR). Grade 3 adverse effects were experienced by $36 \%$ of these patients.

Lim et al. evaluated ceritinib $750 \mathrm{mg}$ daily in ROS1-inhibitor naive patients with ROS1-rearranged NSCLC. ${ }^{30}$ The ORR in this cohort was 62\% (95\% CI, 45-77). The median PFS in this group was 9.3 months (95\% CI, 0-22). The median OS was 24 months (95\% CI, 5-43). Grade 3 or higher adverse events affected $37 \%$ of patients in this study.

\section{BRAF V600E MUTATION}

A combination of dabrafenib and trametinib has been evaluated for NSCLC with BRAF V600E mutation in the firstline setting. ${ }^{31}$ In this phase II study, patients were treated 
Table 1. Summary of select clinical trials of targeted agents for EGFR alterations

\begin{tabular}{|c|c|c|c|c|c|c|c|c|}
\hline & $\begin{array}{l}\text { Study or } \\
\text { studies }\end{array}$ & Phase & Line & Treatment & $\begin{array}{c}\text { \# of } \\
\text { patients }\end{array}$ & ORR $(95 \% \mathrm{Cl})$ & PFS (months) (95\% Cl) & OS (months) (95\% Cl) \\
\hline \multirow[t]{10}{*}{$\begin{array}{c}\text { EGFR exon } \\
19 \\
\text { deletion, } \\
\text { L858R } \\
\end{array}$} & FLAURA $^{5,6}$ & III & First & Osimertinib $80 \mathrm{mg}$ daily vs. standard EGFR-TKI & 556 & $\begin{array}{c}80 \%(75-85) \text { vs. } 76 \% \\
(70-81), \text { OR } 1.27 \\
(0.85-1.90), p=0.24\end{array}$ & $\begin{array}{c}18.9(15.2-21.4) \text { vs. } 10.2 \\
(9.6-11.1), \operatorname{HR} 0.46(0.37-0.57) \\
p<0.001\end{array}$ & $\begin{array}{c}38.6(34.5-41.8) \text { vs. } 31.8 \\
(26.6-36.0), H R 0.80(0.64-1.00) \\
p=0.046\end{array}$ \\
\hline & OPTIMAL & III & First & $\begin{array}{l}\text { Erlotinib } 150 \mathrm{mg} \text { daily vs. carboplatin AUC } 5 \text { D1 and } \\
\text { gemcitabine } 1000 \mathrm{mg} / \mathrm{m}^{\wedge} 2 \mathrm{D} 1, \mathrm{D} 8 \text { of } 21 \text { day cycle }\end{array}$ & 165 & $83 \%$ vs. $36 \%, p<0.0001$ & $\begin{array}{l}13.1(10.58-16.53) \text { vs. } 4.6 \\
(4.21-5.42), \text { HR } 0.16 \\
(0.10-0.26), p<0.0001\end{array}$ & 22.8 vs. 27.2, HR $1.19, p=0.2663$ \\
\hline & EURTAC 9 & III & First & Erlotinib $150 \mathrm{mg}$ daily vs. chemotherapy & 173 & $64 \%$ vs. $18 \%$ & $\begin{array}{l}9.7(8.4-12.3) \text { vs. } 5.2(4.5-5.8) \\
\text { HR } 0.37(0.25-0.54), p<0.0001\end{array}$ & $\begin{array}{l}19.3(14.7-26.8) \text { vs. } 19.5 \text { (16.1-not } \\
\text { assessable), HR 1.04 (0.64-1.68), } \\
\text { p=0.87 }\end{array}$ \\
\hline & $\begin{array}{l}\text { LUX-Lung } \\
3^{10,12}\end{array}$ & III & First & Afatinib $40 \mathrm{mg}$ daily vs. cisplatin plus pemetrexed & 345 & $56 \%$ vs. $23 \%$ & $\begin{array}{l}11.1 \text { vs. } 6.9, \text { HR } 0.58 \\
(0.43-0.78), p=0.001\end{array}$ & $\begin{array}{c}28.2(24.6-33.6) \text { vs. } 28.2 \\
(20.7-33.2), H R 0.88(0.66-1.17) \\
\text { p=0.39 }\end{array}$ \\
\hline & $\begin{array}{l}\text { LUX-Lung } \\
6^{11,12}\end{array}$ & III & First & Afatinib $40 \mathrm{mg}$ daily vs. cisplatin plus gemcitabine & 364 & $66.9 \%$ vs. $23.0 \%, p<0.001$ & $\begin{array}{l}11.0(9.7-13.7) \text { vs. } 5.6(5.1-6.7) \\
\text { HR 0.28 (0.20-0.39), } p<0.0001\end{array}$ & $\begin{array}{c}23.1(20.4-27.3) \text { vs. } 23.5 \\
(18.0-25.6), H R 0.93(0.72-1.22) \\
p=0.61\end{array}$ \\
\hline & $\begin{array}{l}\text { LUX-Lung } \\
7^{13,14}\end{array}$ & II & First & Afatinib $40 \mathrm{mg}$ daily vs. gefitinib $250 \mathrm{mg}$ daily & 319 & $\begin{array}{c}70 \% \text { vs. } 56 \% \text {, OR } 1.873 \\
(1.176-2.985), p=0.0083\end{array}$ & $\begin{array}{c}11.0(0.6-12.9) \text { vs. } 10.9 \\
(9.1-11.5), \operatorname{HR} 0.73(0.57-0.95) \\
p=0.017\end{array}$ & $\begin{array}{l}27.9 \text { vs. } 24.5, \text { HR } 0.86 \text { (0.66-1.12), } \\
p=0.2580\end{array}$ \\
\hline & Patil et al. ${ }^{15}$ & III & First & $\begin{array}{l}\text { Gefitinib } 250 \mathrm{mg} \text { daily vs. pemetrexed } 500 \mathrm{mg} / \mathrm{m}^{\wedge} 2 \\
\text { and carboplatin AUC5 followed by pemetrexed } \\
\text { maintenance }\end{array}$ & 290 & $63.5 \%$ vs. $45.3 \%, p=0.003$ & $\begin{array}{l}8.4(6.3-10.5) \text { vs. } 5.6(4.2-7.0) \\
\text { HR } 0.66(0.513-0.851), p=0.001\end{array}$ & $\begin{array}{c}18 \text { (15.2-20.8) vs. } 22.6(18.6-26.6) \\
\quad H R 0.78(0.56-1.09), p=0.133\end{array}$ \\
\hline & $\begin{array}{l}\text { ARCHER } \\
1050^{16,17}\end{array}$ & III & First & Dacomitinib 45 mg daily vs. gefitinib $250 \mathrm{mg}$ daily & 452 & $\begin{array}{c}75 \%(69-80) \text { vs. } 72 \% \\
(65-77), p=0.4234\end{array}$ & $\begin{array}{c}14.7(11.1-16.6) \text { vs. } 9.2 \\
(9.1-11.0), \operatorname{HR} 0.59(0.47-0.74) \\
p<0.0001\end{array}$ & $\begin{array}{l}34.1(29.5-39.8) \text { vs. } 27.0 \\
(24.4-31.6), \mathrm{HR} 0.748 \\
(0.591-0.947), \mathrm{p}=0.0155\end{array}$ \\
\hline & RELAY $^{18}$ & III & First & $\begin{array}{l}\text { Erlotinib } 150 \mathrm{mg} \text { daily plus ramucirumab } 10 \mathrm{mg} / \mathrm{kg} \\
\text { every } 2 \text { weeks vs. placebo plus erlotinib } 150 \mathrm{mg} \text { daily }\end{array}$ & 449 & $\begin{array}{l}76 \%(71-82) \text { vs. } 75 \% \\
(69-80), p=0.741\end{array}$ & $\begin{array}{l}\text { 19.4 (15.4-21.6) vs. } 12.4 \\
(11.0-13.5), \text { HR } 0.59 \\
(0.46-0.76), p<0.0001\end{array}$ & \\
\hline & NEJ02619 & III & First & $\begin{array}{l}\text { Erlotinib } 150 \mathrm{mg} \text { daily plus bevacizumab } 15 \mathrm{mg} / \mathrm{kg} \\
\text { every } 3 \text { weeks vs. erlotinib } 150 \mathrm{mg} \text { daily }\end{array}$ & 228 & $\begin{array}{l}72 \%(63.1-80.4) \text { vs. } 66 \% \\
(56.5-74.7), p=0.31\end{array}$ & $\begin{array}{l}16.9(14.2-21.0) \text { vs. } 13.3 \\
(11.1-15.3), \mathrm{HR} 0.605 \\
(0.417-0.877), p=0.016\end{array}$ & \\
\hline \multirow[t]{2}{*}{$\begin{array}{l}\text { EGFR exon } \\
20 \\
\text { insertion }\end{array}$} & CHRYSALIS 20 & 1 & Second & $\begin{array}{l}\text { Amivantamab } 1400 \mathrm{mg} \text { weekly for the first four } \\
\text { weeks, then every two weeks }\end{array}$ & 81 & $40 \%(29-51)$ & $8.3(6.5-10.9)$ & $22.8(14.6-\mathrm{NR})$ \\
\hline & $\begin{array}{l}\text { PPP plus } \\
\text { EXCLAIM }^{21}\end{array}$ & $1 / / I$ & $\begin{array}{l}\text { Platinum } \\
\text { pretreated }\end{array}$ & Mobocertinib 160 mg daily & 114 & $28 \%(95 \% \mathrm{Cl}, 20-37)$ & $7.3(5.5-9.2)$ & $24.0(14.6-28.8)$ \\
\hline
\end{tabular}

ORR: Objective response rate CI: Confidence interval PFS: Progression-free survival OS: Overall survival TKI: Tyrosine kinase inhibitor OR: Odds ratio HR: Hazard ratio AUC: Area under the curve NR: Not reached 
Table 2. Summary of select clinical trials of targeted agents with approved molecularly targeted indications in NSCLC

\begin{tabular}{|c|c|c|c|c|c|c|c|c|}
\hline & Study or studies & Phase & Line & Treatment & \# of patients & ORR $(95 \% \mathrm{CI})$ & PFS (months) $(95 \% \mathrm{Cl})$ & $\begin{array}{l}\text { OS (months) } \\
(95 \% \mathrm{CI})\end{array}$ \\
\hline \multirow[t]{3}{*}{$\begin{array}{l}\text { ALK } \\
\text { fusion }\end{array}$} & ALEX 22,23 & III & ALK inhibitor naiive & $\begin{array}{l}\text { Alectinib } 600 \mathrm{mg} \\
\text { BID vs. crizotinib } \\
250 \mathrm{mg} \text { BID }\end{array}$ & 303 & $\begin{array}{c}82.9 \%(76.0-88.5) \text { vs. } 75.5 \% \\
(67.8-82.1), p=0.09\end{array}$ & $\begin{array}{c}34.8(17.7-\mathrm{NE}) \text { vs. } 10.9 \\
(9.1-12.9), \mathrm{HR} 0.43 \\
(0.32-0.58), \mathrm{p}<0.0001\end{array}$ & $\begin{array}{c}\text { NR vs. } 57.4 \\
\text { (34.6-NR), HR } \\
0.67 \\
(0.46-0.98)\end{array}$ \\
\hline & ALTA-1L 24,25 & III & ALK inhibitor naiive & $\begin{array}{c}\text { Brigatinib } 180 \\
\text { mg daily vs. } \\
\text { crizotinib } 250 \mathrm{mg} \\
\text { BID }\end{array}$ & 275 & $\begin{array}{c}74 \% \text { (66-81) vs. } 62 \% \text { (53-70), OR } 1.73 \\
(1.04-2.88), p=0.0342\end{array}$ & $\begin{array}{c}24.0(18.5-N R) \text { vs. } 11 \\
(9.2-12.9), H R 0.49 \\
(0.35-0.68), p<0.0001\end{array}$ & $\begin{array}{l}\text { HR } 0.92 \\
(0.57-1.47), p \\
=0.771\end{array}$ \\
\hline & CROWN $^{26}$ & III & First & $\begin{array}{l}\text { Lorlatinib } 100 \mathrm{mg} \\
\text { daily vs. } \\
\text { crizotinib } 250 \mathrm{mg} \\
\text { BID }\end{array}$ & 296 & $\begin{array}{c}76 \% \text { (68-83) vs. } 58 \%(49-66), \text { OR } 2.25 \\
(1.35-3.89)\end{array}$ & $\begin{array}{l}\text { NR (NR-NR) vs. } 9.3(7.6-11.1), \\
\text { HR } 0.28(0.19-0.41), p<0.001\end{array}$ & $\begin{array}{c}\text { HR } 0.72 \\
(0.41-1.25)\end{array}$ \\
\hline \multirow[t]{3}{*}{$\begin{array}{l}\text { ROS1 } \\
\text { fusion }\end{array}$} & $\begin{array}{l}\text { ALKA-372-001, } \\
\text { STARTRK-1, } \\
\text { STARTRK-2 }{ }^{27}\end{array}$ & $1 / I I$ & ROS1 inhibitor naiive & $\begin{array}{l}\text { Entrectinib } \geq 600 \\
\text { mg daily }\end{array}$ & 161 & $67.1 \%(59.3-74.3)$ & $15.7(11.0-21.1)$ & \\
\hline & PROFILE $1001^{28,29}$ & 1 & ROS1 inhibitor naiive & $\begin{array}{l}\text { Crizotinib } 250 \\
\text { mg BID }\end{array}$ & 53 & $72 \%(58-83)$ & $19.3(15.2-39.1)$ & $\begin{array}{c}51.4 \\
(29.3-N R)\end{array}$ \\
\hline & Lim et al. ${ }^{30}$ & II & $\begin{array}{l}\text { ROS1 inhibitor naiive (except } \\
\text { 2) }\end{array}$ & $\begin{array}{l}\text { Ceritinib } 750 \mathrm{mg} \\
\text { daily }\end{array}$ & 32 & $62 \%(45-77)$ & $9.3(0-22)$ & $24(5-43)$ \\
\hline $\begin{array}{l}\text { BRAF } \\
\text { V6O0E }\end{array}$ & Planchard et al. ${ }^{31}$ & ॥ & First & $\begin{array}{l}\text { Dabrafenib } 150 \\
\text { mg BID and } \\
\text { trametinib } 2 \text { mg } \\
\text { daily }\end{array}$ & 36 & $64 \%(46-79)$ & $14.6(7.0-22.1)$ & 24.6 (12.3-NE) \\
\hline $\begin{array}{l}\text { KRAS } \\
\text { G12C }\end{array}$ & CodeBreaK10032,33 & $\|$ & $\begin{array}{l}\text { Patients progressed following } \\
\text { immunotherapy and/or } \\
\text { platinum-based therapy }\end{array}$ & $\begin{array}{l}\text { Sotorasib } 960 \mathrm{mg} \\
\text { daily }\end{array}$ & 126 & $37.1 \%(28.6-46.2)$ & $6.8(5.1-8.2)$ & 12.5 (10.0-NE) \\
\hline \multirow[t]{2}{*}{$\begin{array}{l}\text { NTRK1/ } \\
2 / 3 \\
\text { fusion }\end{array}$} & $\begin{array}{l}\text { NAVIGATE and } \\
\text { NCT02122913 } \\
\text { N4,35 }\end{array}$ & $1 / / I$ & Heavily pretreated & $\begin{array}{l}\text { Larotrectinib } 100 \\
\text { mg BID }\end{array}$ & 20 & $73 \%(45-92)$ & & 40.7 (17.2-NE) \\
\hline & $\begin{array}{l}\text { ALKA-372-001, } \\
\text { STARTRK-1, } \\
\text { STARTRK-2 }{ }^{34,36}\end{array}$ & $1 / / 1$ & TRK-inhibitor naïve & $\begin{array}{l}\text { Entrectinib, } \\
\text { varying doses }\end{array}$ & 10 with NSCLC & $70 \%(35-93)$ & & $\begin{array}{l}21 \text { (14.9-NE) } \\
\text { for all } 54 \\
\text { patients }\end{array}$ \\
\hline \multirow[t]{2}{*}{$\begin{array}{c}\text { RET } \\
\text { fusion }\end{array}$} & LIBRETTO37 & $1 / / 1$ & $\begin{array}{l}\text { First and post-platinum } \\
\text { treatment }\end{array}$ & $\begin{array}{l}\text { Selpercatinib } 160 \\
\mathrm{mg} \mathrm{BID}\end{array}$ & $\begin{array}{l}39 \text { treatment naïve and } 105 \\
\text { platinum-treated }\end{array}$ & $\begin{array}{l}85 \%(70-94) \text { in treatment naïve and } \\
64 \%(54-73) \text { in platinum-treated }\end{array}$ & $\begin{array}{l}16.5 \text { (13.7-NE) in platinum- } \\
\text { treated patients }\end{array}$ & \\
\hline & ARROW 38 & $1 / / 1$ & $\begin{array}{l}\text { First and post-platinum } \\
\text { treatment }\end{array}$ & $\begin{array}{l}\text { Pralsetinib } 400 \\
\text { mg daily }\end{array}$ & $\begin{array}{l}27 \text { treatment naïve and } 87 \\
\text { platnum-treated }\end{array}$ & $\begin{array}{l}70 \%(50-86) \text { in treatment naïve and } \\
61 \%(50-71) \text { in platinum-treated }\end{array}$ & $\begin{array}{l}9.1(6.1-13.0) \text { in treatment } \\
\text { naïve and } 17.1(12.7-18.4) \text { in } \\
\text { platinum-treated }\end{array}$ & \\
\hline $\begin{array}{l}\text { MET } \\
\text { exon } 14 \\
\text { skipping }\end{array}$ & GEOMETRY 39 & ॥ & Various & $\begin{array}{l}\text { Capmatinib } 400 \\
\mathrm{mg} \mathrm{BID}\end{array}$ & $\begin{array}{l}28 \text { treatment naïve and } 69 \\
\text { who had received one or two } \\
\text { lines of prior therapy }\end{array}$ & $\begin{array}{l}68 \%(48-84) \text { in treatment naïve and } \\
41 \%(29-53) \text { in patients with one or } \\
\text { two prior lines of therapy }\end{array}$ & $\begin{array}{l}12.4(8.2-\mathrm{NE}) \text { in treatment } \\
\text { naïve and 5.4 (4.2-7.0) in } \\
\text { patients with prior treatment }\end{array}$ & \\
\hline
\end{tabular}




\begin{tabular}{|c|c|c|c|c|c|c|c|}
\hline & Study or studies & Phase & Line & Treatment & \# of patients & ORR (95\% CI) & PFS (months) (95\% Cl) \\
$(95 \% \mathrm{Cl})$
\end{tabular}

ORR: Objective response rate CI: Confidence interval PFS: Progression-free survival OS: Overall survival OR: Odds ratio HR: Hazard ratio NE: Not estimable NR: Not reached 
with dabrafenib $150 \mathrm{mg}$ BID and trametinib $2 \mathrm{mg}$ daily. The ORR in this study was 64\% (95\% CI, 46-79). The patients receiving this combination had a median OS of 24.6 months (95\% CI, 12.3-NE) and median PFS of 14.6 months (7.0-22.1). Grade 3 or higher adverse effects were experienced in $69 \%$ of patients.

\section{KRAS G12C MUTATION}

Sotorasib has recently gained accelerated approval for the treatment of KRAS G12C-mutated NSCLC in the postchemotherapy, and optimally post chemoimmunotherapy, setting. The CodeBreaK100 study provided the data to support its use in this indication. ${ }^{32,33}$ In this study, patients received sotorasib $960 \mathrm{mg}$ daily in patients who had progressed on immunotherapy and/or platinum-based chemotherapy. The ORR was $37.1 \%$ (95\% CI, 28.6-46.2). Patients showed a median PFS of 6.8 months (95\% CI, 5.1-8.2). The median OS was 12.5 months (95\% CI, 10.0-NE). Grade 3 treatment-related adverse events affected $19.8 \%$ of patients, and one had a grade 4 adverse event. Of note, the use of proton pump inhibitors with sotorasib may substantially reduce drug levels and should be avoided.

\section{NTRK $1 / 2 / 3$ FUSION}

Larotrectinib and entrectinib are options for therapy in NSCLC patients with NTRK 1/2/3 fusions. Lin et al. pooled results from the NAVIGATE and NCT02122913 studies and showed that 20 patients with NSCLC and NTRK fusions treated with Larotrectinib $100 \mathrm{mg}$ BID had an ORR of $73 \%$ (95\% CI, 45-92). ${ }^{34,35}$ These patients had a median OS of 40.7 months (95\% CI, 17.2-NE). Two patients (10\%) experienced treatment-related grade 3 adverse events.

Doebele et al. evaluated the use of entrectinib in patients with advanced or metastatic NTRK fusions in a combination of phase I and II trials. ${ }^{36}$ Of the 54 patients, 10 had NTRK fusion NSCLC. These patients showed an ORR of $70 \%$ (95\% CI, 35-93). Median OS for the entire cohort, not just the NSCLC patients, was 21 months (95\% CI, 14.9-NE). Serious treatment-related adverse events affected $10 \%$ of the NTRK fusion-positive patients and $9 \%$ of the overall safety population.

\section{RET FUSION}

Selpercatinib and pralsetinib have recently gained accelerated approval for the management of RET fusion NSCLC. Selpercatinib was evaluated in patients with prior platinum-based chemotherapy or without prior treatment in the LIBRETTO phase I/II study. ${ }^{37}$ The phase II dose was selpercatinib $160 \mathrm{mg}$ BID. The patients with prior platinum-based chemotherapy had an ORR of $64 \%$ (95\% CI, 54-73). This cohort had a median PFS of 16.5 months (95\% CI, 13.7-NE). In the treatment naïve cohort, the ORR was 85\% (95\% CI, 70-94). Median OS was not reached in this group, and neither group reached median OS. Grade 3 or higher treatment-related adverse events were experienced by $28 \%$ of patients.

The use of pralsetinib in patients with RET rearrangements was tested in the ARROW study. ${ }^{38}$ Similar to LIBRETTO, this study was a phase I/II evaluation of patients treated with pralsetinib, with the phase II dose of $400 \mathrm{mg}$ daily. Patients were separated into prior platinum-based chemotherapy and treatment naïve groups. The ORR for these groups were $61 \%$ (95\% CI, 50-71) and 70\% (50-86), respectively. Median PFS was 17.1 months (95\% CI, 12.7-18.4) for the platinum-treated group and 9.1 months (95\% CI, 6.1-13.0) in the treatment naïve group. Grade 3 or worse treatment-related adverse events affected $48 \%$ of patients in the NSCLC safety population.

\section{MET EXON 14 SKIPPING MUTATION}

Capmatinib and tepotinib have been approved by the FDA for the treatment of advanced NSCLC with MET exon 14 skipping mutations. The GEOMETRY trial provided support for capmatinib's approval for this indication. ${ }^{39}$ In this phase II study, patients with this mutation were binned into cohorts based on prior treatment regimens and received capmatinib at a dose of $400 \mathrm{mg}$ BID. The ORR for treatment naïve patients receiving this therapy was 68\% (95\% CI, 48-84). The ORR for patients with one or two prior lines of therapy was $41 \%$ (95\% CI, 29-53). Median PFS for these groups were 12.4 months (95\% CI, 8.2-NE) and 5.4 months (95\% CI, 4.2-7.0), respectively. Grade 3 or higher adverse effects were experienced by $67 \%$ of patients.

Tepotinib was studied for NSCLC with MET exon 14 skipping mutations in the phase II VISION study. ${ }^{40}$ Enrolled patients were allowed to have up to two prior lines of therapy. The ORR for the treated population was $46 \%$ (95\% CI, 36-57). The median PFS was 8.5 months (95\% CI, 6.7-11.0). The median overall survival data was not mature, but it was reported as 17.1 months (95\% CI, 12.0-26.8). Topotinib-related grade 3 or higher adverse events occurred at a frequency of $28 \%$.

\section{CONCLUSION}

The impressive studies above have provided exciting improvements for the management of patients with molecularly-altered NSCLC. Importantly, they have provided hope for our patients with new and effective first- and subsequent-line options for their cancer. Notably, the pace of approvals of these agents seems to be quickening, with several gaining accelerated approval over the past couple of years. Future studies will attempt to refine and expand on these options to continue pushing to improve outcomes for patients with NSCLC.

\section{FUTURE DIRECTIONS}

The continued success and growth of molecularly directed therapy will rely on refining treatments for current targets, developing effective treatments for known targets without 
Preferred targeted therapy (first-line unless otherwise indicated)

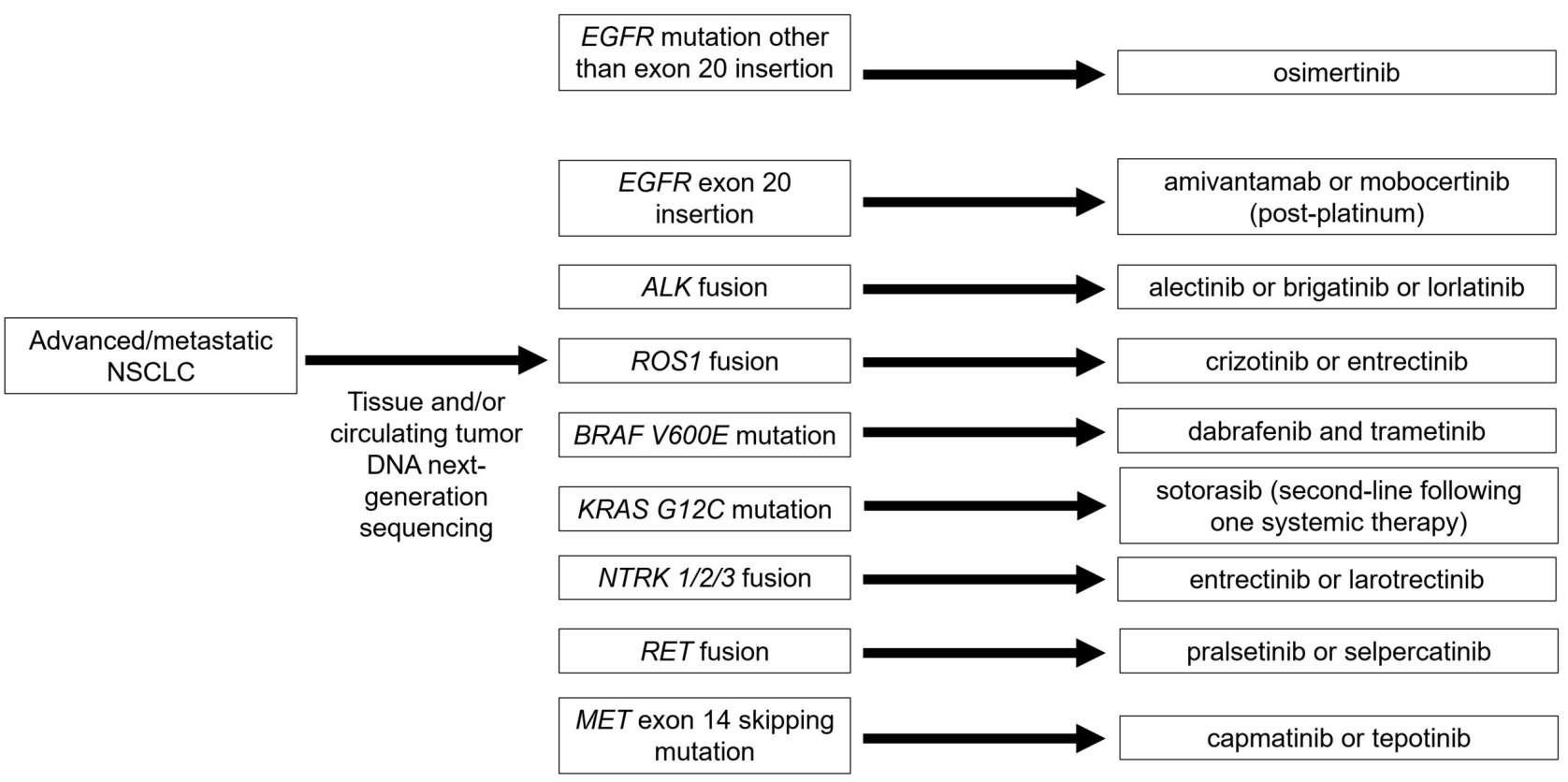

Figure 1. Preferred molecularly targeted agents are shown for each actionable mutation in NSCLC

currently approved treatments, and identifying new molecular targets for patients with advanced or metastatic NSCLC.

Agents targeting HER2 are likely to be added as the next wave of targeted therapies available to clinicians to treat their advanced NSCLC patients. Trastuzumab Deruxtecan has been granted breakthrough FDA designation based on results from the currently active DESTINY-Lung01 trial. ${ }^{41}$ This trial showed a 55\% ORR (95\% CI, 44-65), median PFS of 8.2 months (95\% CI, 6.0-11.9), and median OS of 17.8 months (95\% CI, 13.8-22.1) in patients refractory to standard treatment. Similarly, poziotinib has been granted FDA fast track designation for patients harboring HER2 exon 20 mutations based on findings from a phase II trial demonstrating an ORR of $58 \%$ (95\% CI, 40.9-73.0). ${ }^{42}$

The promising progress of recent years of molecularly targeted therapy in the NSCLC field will hopefully serve as a harbinger for continued discovery that will improve quality and duration of life for our patients.

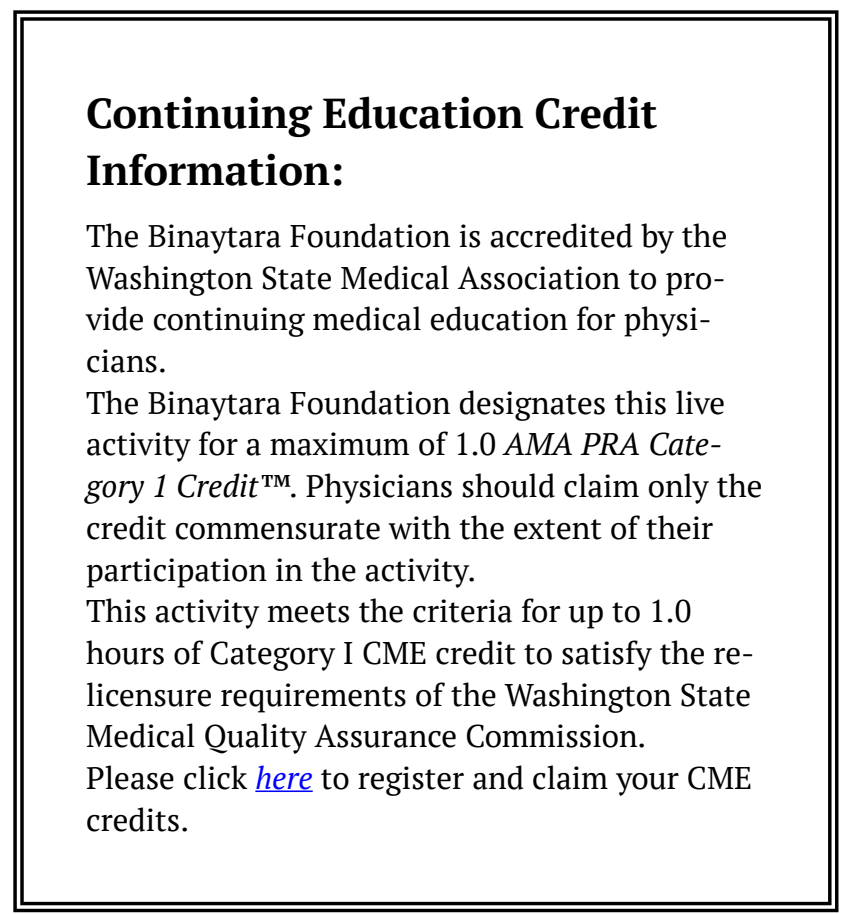

Submitted: December 15, 2021 PST, Accepted: December 25, 2021 PST 


\section{REFERENCES}

1. Siegel RL, Miller KD, Jemal A. Cancer statistics, 2020. CA Cancer J Clin. 2020;70(1):7-30. doi:10.3322/c aac. 21590

2. Sholl LM, Aisner DL, Varella-Garcia M, et al. Multiinstitutional Oncogenic Driver Mutation Analysis in Lung Adenocarcinoma: The Lung Cancer Mutation Consortium Experience. J Thorac Oncol. 2015;10(5):768-777. doi:10.1097//TO.0000000000000 $\underline{516}$

3. Tfayli A, Rafei H, Mina A, et al. Prevalence of EGFR and ALK Mutations in Lung Adenocarcinomas in the Levant Area - a Prospective Analysis. Asian Pac J Cancer Prev. 2017;18(1):107-114. doi:10.22034/APIC P.2017.18.1.107

4. Allen T, Xiao Y, Abraham A, et al. Prevalence of ALK mutations in advanced NSCLC patients in the United States: Analysis with a real world oncology database. J Clin Oncol.

2020;38(15_suppl):e21586-e21586. doi:10.1200/JCO.2 020.38.15 suppl.e21586

5. Soria JC, Ohe Y, Vansteenkiste J, et al. Osimertinib in Untreated EGFR-Mutated Advanced Non-SmallCell Lung Cancer. N Engl J Med. 2018;378(2):113-125. doi:10.1056/NEJMoa1713137

6. Ramalingam SS, Vansteenkiste J, Planchard D, et al. Overall Survival with Osimertinib in Untreated, EGFR-Mutated Advanced NSCLC. $N$ Engl J Med. 2020;382(1):41-50. doi:10.1056/NEJMoa1913662

7. Zhou C, Wu YL, Chen G, et al. Erlotinib versus chemotherapy as first-line treatment for patients with advanced EGFR mutation-positive non-smallcell lung cancer (OPTIMAL, CTONG-0802): a multicentre, open-label, randomised, phase 3 study. Lancet Oncol. 2011;12(8):735-742. doi:10.1016/S147 $\underline{0-2045(11) 70184-X}$

8. Zhou C, Wu YL, Chen G, et al. Final overall survival results from a randomised, phase III study of erlotinib versus chemotherapy as first-line treatment of EGFR mutation-positive advanced non-small-cell lung cancer (OPTIMAL, CTONG-0802). Ann Oncol. 2015;26(9):1877-1883. doi:10.1093/annonc/mdv276

9. Rosell R, Carcereny E, Gervais R, et al. Erlotinib versus standard chemotherapy as first-line treatment for European patients with advanced EGFR mutationpositive non-small-cell lung cancer (EURTAC): a multicentre, open-label, randomised phase 3 trial. Lancet Oncol. 2012;13(3):239-246. doi:10.1016/S147 $\underline{0-2045(11) 70393-X}$
10. Sequist LV, Yang JCH, Yamamoto N, et al. Phase III Study of Afatinib or Cisplatin Plus Pemetrexed in Patients With Metastatic Lung Adenocarcinoma With EGFR Mutations. J Clin Oncol. 2013;31(27):3327-3334. doi:10.1200/JCO.2012.44.2806

11. Wu YL, Zhou C, Hu CP, et al. Afatinib versus cisplatin plus gemcitabine for first-line treatment of Asian patients with advanced non-small-cell lung cancer harbouring EGFR mutations (LUX-Lung 6): an open-label, randomised phase 3 trial. Lancet Oncol. 2014;15(2):213-222. doi:10.1016/S1470-2045(13)7060 4-1

12. Yang JCH, Wu YL, Schuler M, et al. Afatinib versus cisplatin-based chemotherapy for EGFR mutationpositive lung adenocarcinoma (LUX-Lung 3 and LUXLung 6): analysis of overall survival data from two randomised, phase 3 trials. Lancet Oncol. 2015;16(2):141-151. doi:10.1016/S1470-2045(14)7117 $\underline{3-8}$

13. Park K, Tan EH, O’Byrne K, et al. Afatinib versus gefitinib as first-line treatment of patients with EGFR mutation-positive non-small-cell lung cancer (LUXLung 7): a phase 2B, open-label, randomised controlled trial. Lancet Oncol. 2016;17(5):577-589. do i:10.1016/S1470-2045(16)30033-X

14. Paz-Ares L, Tan EH, O’Byrne K, et al. Afatinib versus gefitinib in patients with EGFR mutationpositive advanced non-small-cell lung cancer: overall survival data from the phase IIb LUX-Lung 7 trial. Ann Oncol. 2017;28(2):270-277. doi:10.1093/annonc/ mdw611

15. Patil VM, Noronha V, Joshi A, et al. Phase III study of gefitinib or pemetrexed with carboplatin in EGFR-mutated advanced lung adenocarcinoma. ESMO Open. 2017;2(1):e000168. doi:10.1136/esmoop en-2017-000168

16. Wu YL, Cheng Y, Zhou X, et al. Dacomitinib versus gefitinib as first-line treatment for patients with EGFR-mutation-positive non-small-cell lung cancer (ARCHER 1050): a randomised, open-label, phase 3 trial. Lancet Oncol. 2017;18(11):1454-1466. d oi:10.1016/S1470-2045(17)30608-3

17. Mok TS, Cheng Y, Zhou X, et al. Updated Overall Survival in a Randomized Study Comparing Dacomitinib with Gefitinib as First-Line Treatment in Patients with Advanced Non-Small-Cell Lung Cancer and EGFR-Activating Mutations. Drugs. 2021;81(2):257-266. doi:10.1007/s40265-020-01441-6 
18. Nakagawa K, Garon EB, Seto T, et al. Ramucirumab plus erlotinib in patients with untreated, EGFR-mutated, advanced non-small-cell lung cancer (RELAY): a randomised, double-blind, placebo-controlled, phase 3 trial. Lancet Oncol. 2019;20(12):1655-1669. doi:10.1016/S1470-2045(19)3 $\underline{0634-5}$

19. Saito H, Fukuhara T, Furuya N, et al. Erlotinib plus bevacizumab versus erlotinib alone in patients with EGFR-positive advanced non-squamous nonsmall-cell lung cancer (NEJ026): interim analysis of an open-label, randomised, multicentre, phase 3 trial. Lancet Oncol. 2019;20(5):625-635. doi:10.1016/S 1470-2045(19)30035-X

20. Park K, Haura EB, Leighl NB, et al. Amivantamab in EGFR Exon 20 Insertion-Mutated Non-Small-Cell Lung Cancer Progressing on Platinum Chemotherapy: Initial Results From the CHRYSALIS Phase I Study. I Clin Oncol. 2021;39(30):3391-3402. doi:10.1200/ICO.2 1.00662

21. Zhou C, Ramalingam SS, Kim TM, et al. Treatment Outcomes and Safety of Mobocertinib in Platinum-Pretreated Patients With EGFR Exon 20 Insertion-Positive Metastatic Non-Small Cell Lung Cancer: A Phase 1/2 Open-label Nonrandomized Clinical Trial. JAMA Oncol. Published online October 14, 2021:e214761. doi:10.1001/jamaoncol.2021.4761

22. Peters S, Camidge DR, Shaw AT, et al. Alectinib versus Crizotinib in Untreated ALK-Positive NonSmall-Cell Lung Cancer. N Engl J Med. 2017;377(9):829-838. doi:10.1056/NEJMoa1704795

23. Mok T, Camidge DR, Gadgeel SM, et al. Updated overall survival and final progression-free survival data for patients with treatment-naive advanced ALK-positive non-small-cell lung cancer in the ALEX study. Ann Oncol. 2020;31(8):1056-1064. doi:10.1016/ j.annonc.2020.04.478

24. Camidge DR, Kim HR, Ahn MJ, et al. Brigatinib versus Crizotinib in ALK-Positive Non-Small-Cell Lung Cancer. N Engl J Med. 2018;379(21):2027-2039. doi:10.1056/NEJMoa1810171

25. Camidge DR, Kim HR, Ahn MJ, et al. Brigatinib Versus Crizotinib in Advanced ALK Inhibitor-Naive ALK-Positive Non-Small Cell Lung Cancer: Second Interim Analysis of the Phase III ALTA-1L Trial. J Clin Oncol. 2020;38(31):3592-3603. doi:10.1200/JCO.20.00 $\underline{505}$

26. Shaw AT, Bauer TM, Marinis F de, et al. First-Line Lorlatinib or Crizotinib in Advanced ALK-Positive Lung Cancer. N Engl J Med. Published online November 18, 2020. doi:10.1056/NEJMoa2027187
27. Dziadziuszko R, Krebs MG, De Braud F, et al. Updated Integrated Analysis of the Efficacy and Safety of Entrectinib in Locally Advanced or Metastatic ROS1 Fusion-Positive Non-Small-Cell Lung Cancer. J Clin Oncol. 2021;39(11):1253-1263. do $\mathrm{i}: 10.1200 / \mathrm{JCO} .20 .03025$

28. Shaw AT, Yeap BY, Solomon BJ, et al. Effect of crizotinib on overall survival in patients with advanced non-small-cell lung cancer harbouring ALK gene rearrangement: a retrospective analysis. Lancet Oncol. 2011;12(11):1004-1012. doi:10.1016/S1470-20 45(11)70232-7

29. Shaw AT, Riely GJ, Bang YI, et al. Crizotinib in ROS1-rearranged advanced non-small-cell lung cancer (NSCLC): updated results, including overall survival, from PROFILE 1001. Ann Oncol. 2019;30(7):1121-1126. doi:10.1093/annonc/mdz131

30. Lim SM, Kim HR, Lee JS, et al. Open-Label, Multicenter, Phase II Study of Ceritinib in Patients With Non-Small-Cell Lung Cancer Harboring ROS1 Rearrangement. J Clin Oncol. 2017;35(23):2613-2618. doi:10.1200/JCO.2016.71.3701

31. Planchard D, Smit EF, Groen HJM, et al. Dabrafenib plus trametinib in patients with previously untreated BRAFV600E-mutant metastatic non-small-cell lung cancer: an open-label, phase 2 trial. Lancet Oncol. 2017;18(10):1307-1316. doi:10.10 16/S1470-2045(17)30679-4

32. Hong DS, Fakih MG, Strickler JH, et al. KRASG12C Inhibition with Sotorasib in Advanced Solid Tumors. N Engl J Med. 2020;383(13):1207-1217. doi:10.1056/N EJMoa1917239

33. Skoulidis F, Li BT, Dy GK, et al. Sotorasib for Lung Cancers with KRAS p.G12C Mutation. N Engl J Med. Published online June 4, 2021. doi:10.1056/NEJMoa21 $\underline{03695}$

34. Drilon A, Laetsch TW, Kummar S, et al. Efficacy of Larotrectinib in TRK Fusion-Positive Cancers in Adults and Children. $N$ Engl J Med. 2018;378(8):731-739. doi:10.1056/NEJMoa1714448

35. Lin JJ, Kummar S, Tan DSW, et al. Long-term efficacy and safety of larotrectinib in patients with TRK fusion-positive lung cancer. J Clin Oncol. 2021;39(15_suppl):9109-9109. doi:10.1200/ICO.202 1.39.15 suppl.9109

36. Doebele RC, Drilon A, Paz-Ares L, et al. Entrectinib in patients with advanced or metastatic NTRK fusion-positive solid tumours: integrated analysis of three phase 1-2 trials. Lancet Oncol. 2020;21(2):271-282. doi:10.1016/S1470-2045(19)3069 $1-6$ 
37. Drilon A, Oxnard GR, Tan DSW, et al. Efficacy of Selpercatinib in RET Fusion-Positive Non-Small-Cell Lung Cancer. N Engl J Med. Published online August 26, 2020. doi:10.1056/NEJMoa2005653

38. Gainor JF, Curigliano G, Kim DW, et al. Pralsetinib for RET fusion-positive non-small-cell lung cancer (ARROW): a multi-cohort, open-label, phase 1/2 study. Lancet Oncol. 2021;22(7):959-969. doi:10.1016/ $\underline{\mathrm{S} 1470-2045(21) 00247-3}$

39. Wolf J, Seto T, Han JY, et al. Capmatinib in MET Exon 14-Mutated or MET-Amplified Non-Small-Cell Lung Cancer. N Engl J Med. 2020;383(10):944-957. do i:10.1056/NEJMoa2002787
40. Paik PK, Felip E, Veillon R, et al. Tepotinib in Non-Small-Cell Lung Cancer with MET Exon 14 Skipping Mutations. N Engl J Med. Published online May 28, 2020. doi:10.1056/NEJMoa2004407

41. Li BT, Smit EF, Goto Y, et al. Trastuzumab Deruxtecan in HER2-Mutant Non-Small-Cell Lung Cancer. N Engl J Med. Published online September 18, 2021. doi:10.1056/NEJMoa2112431

42. Heymach J, Negrao M, Robichaux J, et al. OA02.06 A Phase II Trial of Poziotinib in EGFR and HER2 exon 20 Mutant Non-Small Cell Lung Cancer (NSCLC). J Thorac Oncol. 2018;13(10):S323-S324. doi:10.1016/j.jt ho.2018.08.243 